\title{
The effect of positioning eggs on hatchability and embryonic mortality of the Japanese quails (Coturnix japonica)
}

\author{
Waseem Ali Vistro ${ }^{1 *}$, Qudratullah Kalwar ${ }^{2}$, Illahi Bux Kalhoro ${ }^{1}$, Nasir \\ Rajput $^{1}$, Abdul Sattar Baloch ${ }^{1}$, Zafar Ali Khoso ${ }^{2}$, Arab Khan Lund ${ }^{2}$, \\ Mazhar Mangi ${ }^{1}$ and Muhammad Azhar Memon ${ }^{1}$ \\ 1. Faculty of Animal Husbandry and Veterinary Sciences, Sindh Agriculture University Tandojam-Pakistan \\ 2. Shaheed Benazir Bhutto University of veterinary and animal sciences Sakrand, Sindh-Pakistan \\ *Corresponding author's email: drwaseemvistro@gmail.com \\ Citation \\ Waseem Ali Vistro, Qudratullah Kalwar, Illahi Bux Kalhoro, Nasir Rajput, Abdul Sattar Baloch, Zafar Ali Khoso, \\ Arab Khan Lund, Mazhar Mangi and Muhammad Azhar Memon. The effect of positioning eggs on hatchability and \\ embryonic mortality of the Japanese quails (Coturnix japonica). Pure and Applied Biology. Vol. 8, Issue 2, pp1505- \\ 1509. http://dx.doi.org/10.19045/bspab.2019.80091
}

Received: 12/02/2019 Revised: 15/05/2019

Accepted: $15 / 05 / 2019$

Online First: 17/05/2019

\section{Abstract}

In the last ten years, the little known about Japanese quail (Coturnix Japonica) commonly known as "Bater", has been introduced in the progressing poultry industry of Pakistan. Study was planned to investigate the effect of various positions and condition of quail eggs on embryonic mortality, hatchability and chick weight. Total $(n=150)$ fertile eggs of Japanese quails were grouped into A (vertical position with pointed end upward), B (vertical position with pointed end downward) and C (horizontal position) with average weight 10.87, 10.52 and 10.24 grams respectively. Statistically data was analyzed by determining the mean and standard deviation for each parameter. The group-A eggs weight was significantly higher $(\mathrm{P}<0.05)$ than other groups. The rate of early embryonic mortality was $8 \%, 12 \%$, and $14 \%$ in dehydrated, infected and weak embryo respectively while $6 \%$ in late embryonic mortality in group-A. By the considering these parameters in group-B revealed $6 \%, 10 \%, 16 \%$ in early while $8 \%$ in late mortality. Similarly the eggs of group$\mathrm{C}$ have $10 \%, 4 \%, 10 \%$ in case of early and $12 \%$ was recorded in late embryonic mortality. Hence overall embryonic mortality was low in group C (36\%) compared with group A (40\%) and B $(40 \%)$. The hatchability rate was recorded high in group C $(64 \%)$ than A $(60 \%)$ and B $(60 \%)$. Overall the horizontal position showed positive effects on chick weight and hatchability rate.

Keywords: Egg; Embryonic mortality; Hatchability; Japanese quail; Positioning

\section{Introduction}

The Japanese quails are contributing to broiler and layer type commercial quails. In the last ten years, the little known $C$. Japonica commonly known as "Bater", has been introduced in the progressing poultry industry of Pakistan.
The position of eggs during incubation changes the exposed surface area, loss of water due to temperature and relative humidity and affecting the hatchability obliquely. Moreover initial egg weight are lost $2 \%$ after day seven of storage at room temperature $[\mathbf{1 , 2}]$. Hatchability of quail eggs 
may reduce up to $4 \%$ after day four of incubation even under the optimal circumstances [3, 4]. Many factors can influence the quality of hatching and embryo growth such as improper position of eggs and offensive rotation at the time of incubation. But the static incubation of eggs are unfavorable for embryo development, while careful and automatic rotation of eggs may reduce the irregular adhesions of embryo [5, 6].

Hatching eggs are kept at cool temperatures for long period to improve hatchability of eggs [7]. In broiler production, it is clearly suggested that eggs must be stored in incubator for one day to three week prior to incubation that will result in loss of egg water contents by evaporation for better hatchingegg quality [8, 9]. However, embryo development as well as egg hatchability is affected due to extreme low or intense loss of water [10-12].

Therefore, this study was planned to investigate the effect of different positions and conditions of Japanese quail's eggs during incubation on the basis of early and late embryonic mortality and hatchability.

\section{Materials and methods}

\section{Study Area}

The study was carried out to determine the effect of egg condition and positioning on hatchability and embryonic mortality of Japanese quail by adjusting the eggs in different positions i.e. vertical with pointed end upward and downward, and with horizontal position. The $n=150$ eggs of Japanese quail was obtained from the Department of Poultry Husbandry, Faculty of Animal Husbandry and Veterinary Sciences, Tandojam, Sindh (Table 1).

Table 1. Experimental design

\begin{tabular}{|c|c|c|c|}
\hline $\begin{array}{c}\text { Experimental } \\
\text { groups }\end{array}$ & Position of Eggs & No. of Eggs & $\begin{array}{l}\text { Position in } \\
\text { Sketch }\end{array}$ \\
\hline A & $\begin{array}{c}\text { Vertical position with pointed end } \\
\text { upward }\end{array}$ & 50 & \\
\hline B & $\begin{array}{c}\text { Vertical position with pointed end } \\
\text { downward }\end{array}$ & 50 & \\
\hline $\mathrm{C}$ & Horizontal Position & 50 & \\
\hline
\end{tabular}

\section{Selection of eggs}

The eggs were collected, checked and graded according to the condition of eggs into four categories i.e., dehydrated, week, infected and healthy embryo for incubation. The rejected eggs were replaced by fertile eggs during egg collection and selection. Candling was performed on $3^{\text {rd }}, 9^{\text {th }}$ and $14^{\text {th }}$ day of incubation in each group randomly. Eggs were incubated at $99.6^{\circ} \mathrm{F}$ with relative humidity was $65-75 \%$. Temperature and humidity were observed on the daily bases and turning of eggs was performed regularly three times a day up to 14 day of incubation.
At the final stage (on $18^{\text {th }}$ day) of experiment, hatchability and embryonic mortality were calculated on the basis of following parameters such as normal hatchability rate in standard conditions, weight of eggs before incubation, weight of hatched embryo, calculation of hatchability percentage and embryonic mortality when eggs were placed in horizontal position, vertically up and downward position.

Statistical analysis

The means $(\mathrm{X})$ and standard deviation (SD) for each parameter was computed using Microsoft Excel Software. Group means and 
standard deviation of egg weight, overall embryonic mortality percentage in vertical position with pointed end up and downward, horizontal position and hatchability rate $(\%)$, and finally chick weight $(\mathrm{g} / \mathrm{b})$ of quails were compared using statistical computer software M Stat-C [13].

\section{Results}

\section{Egg weight (g)}

The average eggs weight of Japanese quail of group A, B and C was 10.87, 10.52 and 10.24 $\mathrm{g}$ respectively. It was observed that group $\mathrm{A}$ has maximum egg weight while group $C$ has minimum egg weight. Statistical analysis showed that the egg weight of the groups was highly significant difference $(\mathrm{P}<0.05)$. While computing the Least Significant Difference (LSD) among the mean values, the results showed that there was no significant difference between the means of groups A, B and group $\mathrm{B}, \mathrm{C}$ whereas significant difference is recorded in means of groups $\mathrm{A}$ and $\mathrm{C}$.

\section{Overall embryonic mortality}

The average embryonic mortality was revealed slightly high in group A and B than group $\mathrm{C}$, while the overall embryonic mortality at different positions was recorded as shown in (Table 2)

Hatchability rate $(\%)$

The hatchability percentage was revealed high in group $\mathrm{C}$ followed by group $\mathrm{A}$ and $\mathrm{B}$ (Table 3).

\section{Chick weight (g/b)}

The average chick weight of Japanese quail of group A was high $(6.94 \mathrm{~g} / \mathrm{b})$ followed by group B $(6.83 \mathrm{~g} / \mathrm{b})$ and group C $(6.82 \mathrm{~g} / \mathrm{b})$. While analysis of variance was applied on data for chick weight of group A, B and C the results showed that there was no significant difference $(\mathrm{P}>0.05)$ among the groups.

Table 2. Overall percentage of early \& late embryonic mortality of eggs in various Positions

\begin{tabular}{|c|c|c|c|c|c|c|c|}
\hline \multirow{2}{*}{ Groups } & \multirow{2}{*}{$\begin{array}{l}\text { Position of Eggs In } \\
\text { respect of } \\
\text { Embryonic } \\
\text { Mortality }\end{array}$} & \multicolumn{3}{|c|}{$\begin{array}{c}\text { Condition of Embryo in Early } \\
\text { Mortality \% }\end{array}$} & \multirow{2}{*}{$\begin{array}{c}\text { Total } \\
\text { \%age of } \\
\text { Early } \\
\text { Mortali } \\
\text { ty }\end{array}$} & \multirow{2}{*}{$\begin{array}{c}\text { Late } \\
\text { Mortality } \\
\text { (After } \\
\text { Hatching) } \\
\%\end{array}$} & \multirow{2}{*}{$\begin{array}{c}\text { Overa } \\
\text { ll } \\
\text { \%age }\end{array}$} \\
\hline & & Dehydrated & Infected & Weak & & & \\
\hline A & $\begin{array}{l}\text { Vertical with pointed } \\
\text { end upward }\end{array}$ & 8 & 12 & 14 & 34 & 6 & 40 \\
\hline B & $\begin{array}{c}\text { Vertical with pointed } \\
\text { end downward }\end{array}$ & 6 & 10 & 16 & 32 & 8 & 40 \\
\hline $\mathrm{C}$ & Horizontal position & 10 & 4 & 10 & 24 & 12 & 36 \\
\hline
\end{tabular}

Table 3. Hatchability rate of various Japanese eggs

\begin{tabular}{|c|c|c|c|}
\hline Groups & $\begin{array}{c}\text { Number of Fertile } \\
\text { Eggs }\end{array}$ & $\begin{array}{c}\text { Number of Hatched } \\
\text { Eggs }\end{array}$ & Percentage (\%) \\
\hline A & 50 & 30 & 60 \\
\hline B & 50 & 30 & 60 \\
\hline C & 50 & 32 & 64 \\
\hline
\end{tabular}

\section{Discussion}

In the present study 150 Japanese quail eggs in three groups were stored in incubator at $38^{\circ} \mathrm{C}$ for 18 days. Whereas [7] reported that the 440 Japanese eggs in two groups were store in refrigerator and incubator for 18-20 days. The average egg weight of Japanese quail was high in group A while group C has less. Statistically egg weight of the groups were highly significant $(\mathrm{P}<0.05)$ whereas the results reported by Ibrahim et al., (2005) that egg weight effect on fertility rate and fertile egg 
hatchability were significant $(\mathrm{P}<0.05, \mathrm{P}<0.01)$. This difference of both studies was due to position of egg keeping. However [7] reported that the egg weight loss during storage was linear and reached $4 \%$ at day 20 of incubation. It was not establish relation between storage time and egg weight loss at the time of incubation. The eggs storage showed no statistical influence on hatch weight and also the percentage of egg components.

In the present study the average and overall embryonic mortality of Japanese quail was low in group $\mathrm{C}$ than group $\mathrm{A}$ and $\mathrm{B}$. However, earlier researchers have also exploited low mortality rate in their designed study, which demonstrated the average early and late embryonic mortality was $14.5 \%$ and $11.9 \%$ on the basis of total eggs set and $17.8 \%$ and $14.6 \%$ on the basis of fertile eggs respectively [14]. Nevertheless, embryonic mortality was found high in vertically placed eggs with small end up than the present study [15]. Moreover infertile or early embryo mortality was same as the late embryo death in response to eggs placed in horizontal position with turning during incubation. The static position of eggs caused late embryo death during incubation. The late embryo mortality was measured in the groups kept with horizontal direction without turning $(31 \%)$, vertical position of egg with small end downward $(24 \%)$ and vertical position with pointed end upward (70\%). Following results are nearly agreement with the finding of present study. [16] Found the effect of parental age at the time of hatchability and the embryo mortalities on incubation was not observed on the basis of statistical significant. The significant differences at various stages were analyzed from the point of generally investigated hatching properties among the groups designated for egg weight, any variation associated to the early stage embryo death was not determined as statistically significant. In the study conducted by [17], they were observed that the hatchability rate of fertile eggs and early embryonic death was significantly higher in the group of light weight than the other groups of egg weight. In another research, it was concluded that mid and late embryonic deaths were high in small end upward position eggs, and this position has significant effects on hatchability and cause higher embryonic death at late incubation period in Japanese quail without any effects on body weight of hatched chicks [11].

In present study the average chick weight of Japanese quail of group A was high followed by group $\mathrm{B}$ and group $\mathrm{C}$. Whereas statistically no significant difference $(\mathrm{P}>0.05)$ was observed among the groups. However, the result of study reported by [16] are nonsignificant that indicated the parental age (10 and 20 weeks) of Japanese quails has not a significant effect on the day one old chick weight. While in another study that extended incubation time is responsible for a reduce albumen, yolk weight, albumen, yolk index and High unit value of Rhode Island Red eggs [18]. Presently the hatchability rate was recorded high in group $\mathrm{C}$ than group $\mathrm{A}$ and group $\mathrm{B}$. The results reported by [14] that showed, hatchability was positively correlated with the egg weight. As the egg weight was recorded low in group $\mathrm{C}$ but hatchability rate was high in same group. Similarly the results were also in close agreement with [15] which showed that the eggs placed in horizontal position with proper rotation showed the highest hatchability in incubation, while vertical position (pointed end upward) indicated the low hatchability. Although in present study the eggs of group C were settled in lateral/ horizontal position hatched with high rate. However [7] showed the satisfactory hatchability in designated groups. The very low hatchability was recorded in those eggs which are stored for 20 days (75\%). Egg weight loses up to $4 \%$ at day 20 during storage. The storage of eggs illustrated no statistical influence on hatch weight and also the percentage of egg components.

\section{Conclusion}

On the basis of above findings, there was no negative effect of incubation period as well as temperature. The day old chick was hatched with normal weight and low mortality was observed in egg group of light weight. The lateral/horizontal position showed positive effects on chick weight and hatchability rate. 


\section{Authors' contributions}

Conceived and designed the experiments: WA Vistro, Q Kalwar \& IB Kalhoro, Performed the experiments: WA Vistro, AS Baloch, ZA Khoso \& AK Lund, Analyzed the data: WA Vistro, MA Memon \& M Mangi, Contributed materials/ analysis/ tools: $\mathrm{N}$ Rajput, Wrote the paper: WA Vistro.

\section{Acknowledgement}

The authors are grateful to Dean Faculty of Veterinary and Animal Husbandry, Sindh Agriculture University, Tandojam for his financial assistance.

\section{References}

1. Tiwari AKR \& Maeda T (2005). Effects of Egg Storage Position and Injection of Solutions in Stored Eggs on Hatchability in Chickens (Gallus domesticus): Research note. Poult Sci 42: 356-362.

2. Alkan S, Karabag K, Galic A \& Balcioglu M.S (2008). Effects of genotype and egg weight on hatchability traits and hatching weight in Japanese quail. South African $J$ Anim Sci 38 (3).

3. Imai C, Mowlah A \& Saito J (1986). Storage stability of Japanese of quail (Coturnix japonica) eggs adds room temperature. Poult Sci 5: 474-480.

4. Suksupath S \& Tanpipat S (1991). Improvement of the storage methods for Japanese quail eggs before hatching. Khon Kaen Agri J 19: 156-162.

5. New D A T (1957). A Critical Period for the Turning of Hen's Eggs. J. Embryol Exp Morphol, 5: 293-299.

6. Tona K, Onagbesan O, Bruggeman V, Mertens K \& Decuypere E (2005). Effects of Turning Duration during Incubation on Embryo Growth, Utilization of Albumen, and Stress Regulation. Poul Sci 84: 315320.

7. Vasconcelos de Moraes, TG, Moura Romao J, Evangelista da Silva E, Maciel Cardoso W \& Buxade Carbo S (2008). Incubation of Japanese quail eggs (Coturnix japonica) stored in domestic refrigerator. Live Res for Rurl Devel 20: 10.
8. Samli, HE, Agma A \& Senkoylu N (2005). Effects of storage time and temperature on egg quality in old laying hens. $J$ of Appl Poul Rese 14: 548-553.

9. Kuurman WW, Bailey BA, Koops WJ \& Grossman M (2002). Influence of storage days on the distribution for time of embryonic mortality during incubation. Poult Sci 81: 1-8.

10. Rahn, H and Ar A (1974). The avian egg: Incubation time and water loss. Condor 76: 147- 152.

11. Mehdi B G, Maheri-Sis N, Lotfiand A \& Abedi A S (2010). Effect of Setting Small End Up on Hatchability and Embryo Mortality in Japanese Quail. Glob Vete 4: 592-594.

12. Meir M, Nir A \& Ar A (1984). Increasing hatchability of turkey eggs by matching incubator humidity to shell conductance of individual eggs. Poult Sci 63: 1489-1496.

13. Gomez K A and Gomez A A (2000). Statistics for Agriculture Research (2 ${ }^{\text {nd }}$ Edition). John Wiley and Sons, New York.

14. Khurshid A, Farooq M, Durrani FR, Sarbilandand K \& Manzoor A (2004). Hatching Performance of Japanese Quails. Live Res for RurDevel 16(1): 1-5.

15. Moraes T G V, Romao J M, Teixeira R S C \& Cardoso W M (2008). Effects of Egg Position in Artificial Incubation of Japanese Quail Eggs (Coturnix japonica). Anim Reprod 5: 50-54.

16. Seker I, Kul S \& Bayraktar M (2004). Effects of Parental Age and Hatching Egg Weight of Japanese Quails on Hatchability and Chick Weight. Inter J of Poult Sci 3: 259-265.

17. Ibrahim SI, Kul S \& Baryktar M (2005). Effects of storage period and egg weight of Japanese quail eggs on hatching results. Arch Tierz Dummerston 5: 518-526.

18. Khan M J A, Khan S H, Bukhsh A \& Amin M (2014). The effect of storage time on egg quality and hatchability characteristics of Rhode Island Red (RIR) hens. Vet Arhiv 84: 291-303. 